\title{
Model for assessing the quality of marketing-management education
}

\author{
Jaime Rivera and Víctor Alarcón \\ CENTRUM - Catolica Business School, Lima, Peru
}

\begin{abstract}
Purpose - This study aims to propose and test a model of educational quality in marketing-management by incorporating resource-capability variables that are linked to learning outcomes for students and the competitive positioning of universities.

Design/methodology/approach - Drawing on the resource-dependence theory, this study develops a comprehensive model for measuring educational quality. A sample comprising Spanish university teachers has been used to test the hypothesised relationships by using a two-stage least squares regression analysis while controlling for the possible effect of the public/private nature of the university.

Findings - The results validate the model and show that educational capabilities are reliable variables for predicting the educational quality of marketing-management programmes at Spanish universities.

Research limitations/implications - Similar to all educational research studies, certain problems have been acknowledged with respect to the data and the theoretical constructs that are used in the study. Future studies can replicate this study's model by using more direct objective measures of the theoretical constructs and extend the study to other countries with different educational contexts.

Practical implications - The results provide guidance to marketing teachers at a university in designing high-quality marketing-management educational programmes and in developing self-diagnostic tools that can determine a university's likelihood of competitive success.

Originality/value - This study is one of the few studies to apply the resource-dependence theory to the analysis of the variables associated with the quality of marketing-management education. In doing so, the study presents original multiitem scales to improve the measurement of model constructs.
\end{abstract}

Keywords Educational quality, Educational resources and capabilities, Marketing-management education

Paper type Research paper

\section{Introduction}

As education has increasingly become a competitive factor in a knowledge-based economy, quality in higher education has emerged as an important international issue (Cooke and Leydesdorff, 2006). The European Commission has stated that European universities must achieve and maintain educational excellence if Europe is to achieve its aim of becoming the most competitive knowledge-based economy in the world (Diaconescu, 2009; Pickernell et al., 2010).

Given that marketing managers are frequently involved in decisions that have significant effects on corporate and national economies, education in marketingmanagement is important in promoting national competitiveness (Pride and Ferrell, 2000;

(C) Jaime Rivera and Víctor Alarcón. Published in Journal of Economic Finance and Administrative Science. Published by Emerald Publishing Limited. This article is published under the Creative Commons Attribution (CC BY 4.0) licence. Anyone may reproduce, distribute, translate and create derivative works of this article (for both commercial \& non-commercial purposes), subject to full attribution to the original publication and authors. The full terms of this licence may be seen at http:// creativecommons.org/licenses/by/4.0/legalcode 
JEFAS

25,49

6

Sinkovics and Schlegelmilch, 2000). It has been contended that traditional marketing strategies do not work in the current turbulent business environment (Courtney et al., 1997; Fortier et al., 1998), and the gap between academia and practice is widening (Tapp, 2004). Despite such concerns, the literature suggests that a bias exists in marketing education towards the achievement of academic status through writing and publishing of papers (Baumgartner and Pieters, 2003) rather than towards an improvement in marketing education per se (Straughan and Albers-Miller, 2000). Although some studies have addressed issues in marketing education - such as innovative teaching (Albers-Miller et al., 2001), marketing curricula (Athaide, 2005) and course structure for learning key marketing concepts (Eriksson and Hauer, 2004) - it would seem that insufficient attention is being paid to the quality of contemporary teaching in marketing-management.

The principal reason for the failure to assess the quality of education in marketingmanagement seems to be that different conceptions of higher education lead to different conceptions of educational quality (Bertolin, 2015), making it impossible to arrive at one set of standards for institutional assessment that would be applicable to all countries (UNESCO, 1998). Another possible reason for failure in this field is that few teachers actually participate in what might be called the "education quality agenda", making it difficult to know what teachers regard as "quality" in higher education (Watty, 2003), and further, most of the information about management education is generated in the USA, which is of varying relevance to other countries (Imbs, 1995). Finally, given that the expectations of the public change continuously, previously satisfactory approaches to business education rapidly become outdated (Lengnick-Hall and Sanders, 1997; Kaplan et al., 2010). There is a need to examine the assumptions on which current practices of business education are founded, especially in countries that are seeking to compete on a global scale (Rowley et al., 1998).

The present study proposes an exploratory model of educational quality with a view to identifying and testing the variables that determine the learning outcomes of marketing students and the competitive positioning of universities. This study uses a sample of Spanish universities with an appropriate context because European Commission experts agree that Spain needs to develop intellectual infrastructures associated with marketing skills if the country is to advance an economic model based on high added value (Vanguardia Digital, 2006). In the first national survey of the public image of the Spanish university system, few respondents believed their training prepared them sufficiently for the labour market (El Mundo Digital, 2006). Moreover, a consensus exists that the country needs to improve its education system (Royo, 2010). Indeed, this situation prompted the European Commission to declare that Spanish universities produce too many candidates for unemployment (Davies and Walker, 2014).

Section 2 presents the theoretical framework of the study and extant models of quality of education; Section 3 proposes a model for assessing quality in marketing-management education; Section 4 describes the research design and the main features of the methodology of the empirical study used to test the proposed model; Section 5 presents an in-depth analysis of the results; and Section 6 presents a discussion of the managerial implications and future lines of research.

\section{Theoretical framework}

Despite the abundant literature on educational quality assurance in various countries, there is no consensus on several issues including: definition of educational quality; appropriate assessment indicators; and suitability of the models that have been proposed (Srikanthan and Dalrymple, 2003; Woodhouse, 1996). 
There is considerable disagreement about the definition of educational quality, which is testimony to the complexity and multifaceted nature of the concept (UNICEF, 2000; UNESCO, 2002). The notion of "quality" in education is not only multidimensional but also often subjective (PHARE, 1998), because it depends on the specific goals of the local educational context in which it is being assessed (Adams, 1993; Beeby, 1966). According to Fife and Janosik (1999), defining educational quality is an almost impossible task.

The choice of assessment indicators is similarly problematic (Campbell and Rozsnyai, 2002). According to Ramina (2003), educational quality should be assessed by a set of appropriate indicators and a monitoring system, but this has not been done because educational quality is influenced by factors, many of which are non-measurable. There is therefore widespread disagreement on the selection of objective indicators, especially regarding attempts to quantify concepts such teaching, learning and research (Kaiser and Yonezawa, 2003). These difficulties are exacerbated when attempts are made to make international comparisons because the collection of objective data can be hampered by legislative differences about confidentiality and data protection. Kaiser and Yonezawa (2003) have advocated the use of plain descriptive information as an alternative to objective data.

For assessing educational quality, many suggestions have been made. The "Harvard model", in which the quality of an educational institution is measured against that of the most prestigious institution, suffers from the conceptual weakness of assuming that all customers want the same thing (Fife and Janosik, 1999). Other models have drawn on the philosophy of Total Quality Management (TQM), but these approaches have been criticised because these models tend to focus on the exercise of control (Radford et al., 1997; Salter and Tapper, 2000); the adoption of TQM in academia (in general) is rather limited (Birnbaum and Deshotels, 1999; Vazzana et al., 2000). Other models have been based on pedagogical, cultural, social and economic perspectives. None of these models has achieved widespread acceptance, and the only consensus that appears to have emerged is that the measurement of quality in education will remain an elusive concept (Matsuura, 2003).

\section{Conceptual model and research hypotheses}

\subsection{Paradigm underlying the proposed model}

To overcome the perceived inadequacies of the models noted above (see Section 2), the paradigm of "input-process-outcome" was selected as the basis for this study's proposed model for assessing the quality of marketing-management education.

This paradigm was chosen among the variety of theoretical frameworks in this area of knowledge, as many authors' views coincide to indicated that the topic of quality of education could be defined regarding the human and material resources that are invested (Salam, 2015; REIP, 2002). Also, it conceives of quality education as an ongoing process that transforms the participants (Harvey and Green, 1993). Moreover, this paradigm facilitates that educational quality can be measured by assessing efficiency in the use of resources (Scheerens et al., 2011) and by examining the educational outcomes (Choon Ling et al., 2010).

This paradigm assumes that high-quality educational institutions empower their students with specific skills, knowledge and attitudes required to live and work in a knowledge society (Campbell and Rozsnyai, 2002; European Foundation for Quality Management - EFQM, 1995). This notion of educational quality is appropriate when "learner profiles" are subject to significant changes (Harvey and Knight, 1996).

Another justification for choosing this paradigm is that it allows integration of the theory of resource dependence. Although this theory was developed to study company performance, the present study contends that the resource-dependence theory can also be 
JEFAS

25,49

8

used to explain university competitiveness - which is essentially based on the effective management of educational resources and capabilities (Scott, 2003). Thus, this theory permitted the identification of the level of resources and capabilities used by the institutions in our study and the analysis of how these variables will affect the quality of their learning outcomes.

According to the literature (Lado and Wilson, 1994; Tumer and Crawford, 1994), such capabilities can be classified into four categories:

(1) organisational capabilities;

(2) input-based capabilities;

(3) managerial capabilities; and

(4) technical organisational capabilities.

This classification is used in the present study to describe the hypothesised relationships among the variables of the proposed model for assessing quality in marketing-management education.

\subsection{Variables and hypothesised relationships}

3.2.1 Organisational capabilities (based on outputs). The organisational capabilities of the institution represent the dependent variables of the proposed model. These are the tangible and intangible outputs that provide added value for clients (Lado and Wilson, 1994) and/or enhance corporate reputation and image (Clark and Wheelwright, 1992; Verdin and Williamson, 1994). In the context of marketing education, the organisational capabilities of interest are the learning outcomes of marketing-management education (LOMME) and the competitive outcomes of marketing-management education (COMME).

Lengnick-Hall and Sanders (1997) defined excellence in management education as the achievement of increased knowledge and skills, the application of new knowledge and skills and the positive response of students. Although these general criteria are relevant and useful in evaluating an institution, these should be augmented by consideration of how well an institution responds to criticism of its output. For example, teaching in the field of marketing-management has been criticised for failing to meet the demands of new business environments, to focus on real job markets and to develop links with the business community (Rowley and Rowley, 2000). In addition, it has also been claimed that contemporary business education does not develop interpersonal skills and teamwork (Lerner, 1995) and that it has failed to address issues such as social responsibility and the need for leadership training (UNESCO, 1998). Canzer (1997) emphasised the acquisition of subject knowledge and theoretical concepts, together with the ability to apply this knowledge to real marketing situations. McMullen (1998) suggested that graduates must be able to handle problem-solving, communicate effectively and exercise managerial judgement. Walker et al. (1998) favoured the ability to integrate and use marketing knowledge in a creative and synergistic manner. Adrian and Palmer (1999) and Stern and Tseng (2002) recommended skills include leadership, people management, power distribution, team-building and interpersonal skills to promote effective interaction with subordinates, peers and superiors, as well as linkages to business practice.

The proposed model evaluates the first dependent variable, LOMME, in terms of applicability to the needs of companies, contribution to solving national problems and students' ability to solve real problems, work in teams, develop innovative solutions and demonstrate leadership. 
The second dependent variable is COMME. Universities depend on their reputation and image to ensure funding for educational programmes and research initiatives (Martínez, 2005). As a consequence, the pursuit of prestige is typical of academic institutions worldwide (Brewer, et al., 2002). According to Holdswoth and Nind (2005), universities compete in the "marketplace of public opinion" on the basis of their prestige or reputation. League tables and rankings thus assume great importance as indicators of a university's market position in the educational system and the likelihood that it will acquire the resources it needs (Lombardi et al., 2001). Prestige has been described as a form of "brand-name recognition", which is derived from historical visibility; as such, prestige actually precedes market share (Bok, 2003). Prestige effectively differentiates an institution from its competitors in ways that stakeholders find meaningful. The proposed model evaluates the second dependent variable COMME, based on a university's prestige or reputation as perceived by students, donors, market competitors and employees.

3.2.2 Input-based capabilities. The first of the independent variables in the model is associated with the input-based capabilities of the institution (availability of the various resources: financial, physical, human and technological) that enable any organisation to create and deliver products and services valued by customers (Grant, 1991; Amit and Schoemaker, 1993).

Several studies have confirmed that resource availability enhances learning achievement at all levels of education (Carron and Châu, 1996; Glewwe and Jacoby, 1994). Many universities have recognised that a well-resourced system of incentives attracts and retains the best professors (Henry et al., 1997). These institutions understand that they also require physical resources to meet the challenges of providing education within a changing business environment (Rowley et al., 1998). Institutions from other regions (including Central America, South America and Europe) have also recognised that a link exists between a university's level of competitiveness and the procurement of financial resources (EUA, 2003).

The following hypotheses are proposed:

H1. A higher level of resource availability is associated with (a) a higher level of learning outcomes and (b) a higher level of competitive outcomes.

3.2.3 Managerial capabilities. The next group of independent variables in the model is associated with managerial capabilities: the manager's ability to: develop a beneficial relationship between an organisation and its environment (Lado and Wilson, 1994), design the organisation and coordinate its various functions (Boyatzis, 1999) and provide direction and control in implementing organisational systems to realise organisational objectives (Tumer and Crawford, 1994). In the context of the present study, managerial capabilities are evaluated in terms of: management style, teaching methods and evaluation of faculty performance.

Management style: Pascarella and Terenzini (1991) contended that the organisational environment of an academic department could be more important for student learning than the subject matter itself. "Participatory" management style promotes the fulfilment of a university's social responsibilities (Neave, 1998; UNESCO, 1998) and provides a climate for optimal adjustment to changing societal conditions (Dill, 2003). This management style is also said to provide an atmosphere in which teachers can focus on instruction and student achievement (Wyman, 2001), thus fostering "learning departments" (Walvoord et al., 2000). In this regard, quality assurance is increasingly based on the autonomous participation of all organisational members in the pursuit of quality, rather than on explicit external quality control (Frackmann, 2000; Leithwood and Menzies, 1998). 
JEFAS

25,49

The following hypotheses are proposed with regard to the relationship between management style and competitive outcomes:

H2.1 A higher level of participatory management style is associated with: a higher level of learning outcomes and a higher level of competitive outcomes.

H2.2 A higher level of non-participatory management style is associated with (a) a higher level of learning outcomes and (b) a higher level of competitive outcomes.

For teaching methods, we assess whether the academic staff are adequately conveying the knowledge they wish to impart (Frost and Fukami, 1997). Several studies support that teaching methods should aim to develop critical thinking as a problem-solving tool (Bok, 1986; Dubois, 1995). The current teaching method posits the lecturer as the authority from whom all knowledge emanates (Rowley and Rowley, 2000), with the students posited as passive recipients of information (Lengnick-Hall, 1996), encouraging an algorithmic reading of reality (Bergadaà, 1990) and the development of resources that are not actually used in business practice (Cova et al., 1994).

It has been contended that marketing-management education requires non-structured teaching methods that involve students as active participants in the learning process instead (Alavi, et al., 1995; Leidner and Jarvenpaá, 1995) and co-producers of their training (Lengnick-Hall and Sanders, 1997), and this is consistent with contemporary developments in organisational management, which encourage teamwork and good interpersonal skills (Baldwin et al., 1997). UNESCO (1998) has stated that higher education must implement pedagogical methods based on participatory knowledge if graduates are to learn how to be innovative and creative in their future work.

On the basis of the above discussion, the following alternative hypotheses are proposed:

H3.1 A higher level of non-structured teaching methods is associated with (a) a higher level of learning outcomes and (b) a higher level of competitive outcomes.

H3.2 A higher level of structured teaching methods is associated with (a) a higher level of learning outcomes and (b) a higher level of competitive outcomes.

Evaluation of faculty performance can be done by: government-imposed and/or external stakeholders' criteria. The first refers to the assessment of faculty performance on the basis of government-mandated criteria (such as seniority and "civil service" procedures). The second refers to the assessment of faculty performance by student surveys, academic and scientific publishing and consultancies.

Cave et al. (1997) have suggested that academic quality is equivalent to the quality of teaching at a university. The reaction of students to a course is a way of determining how well a teaching system is working - because education is a service in which the participation of the customer (student) influences both the service process (learning) and the results of that service process (Lengnick-Hall and Sanders, 1997). In addition, because academic quality is also associated with sharing information on best practices (Zhou, 2000), faculty performance can be assessed on the basis of the number of textbooks and educational materials that are published and the number of consulting contracts that are secured for the university. The publication of research papers in scholarly journals and conferences represents an additional criterion of faculty performance; such publications not only complement effective teaching but also represent the accepted sine qua non of academic excellence (Braimoh, 2002).

The following alternative hypotheses are proposed with regard to the relationship between the evaluation of faculty performance and the learning outcomes and competitive outcomes: 
H4.1 A higher level of government-imposed criteria in the evaluation of faculty performance is associated with (a) a higher level of learning outcomes and (b) a higher level of competitive outcomes.

Management education

H4.2 A higher level of external stakeholder criteria in the evaluation of faculty performance is associated with (a) a higher level of learning outcomes and (b) a higher level of competitive outcomes.

3.2.4 Technical organisational capabilities. Technical organisational capabilities are essentially the talents and skills that enable inputs to be turned into outputs (Lado et al., 1992; Green, 1999). They represent sources of competitive advantage because they are often difficult to copy and remain embedded in the tacit routines and practices of the organisation (Kogut and Zander, 1996).

These capabilities are assessed in terms of the variable teacher qualification. Educational research has established that, in all forms of education, positive relationships exist between years of teaching experience and student outcomes (Greenwald et al., 1996) and between teachers' academic qualifications and learning outcomes (Strauss and Vogt, 2001). These relationships have been confirmed at the level of higher education, where quality has been positively associated with the level of education and qualifications of faculty members (Ramina, 2003; Pawlowski, 2004). Also, there is a relationship between the level of international experience of teachers and the quality of education (Heyl and McCarthy, 2003).

The following hypothesis is proposed between variables, teacher qualification, learning outcomes and competitive outcomes:

H5. A higher level of teacher qualification is associated with (a) a higher level of learning outcomes and (b) a higher level of competitive outcomes.

3.2.5 Control variable. Because the private or public nature of an educational institution might affect the perception and use of variables associated with educational quality, the proposed model includes a dichotomous control variable that indicates the nature of the university ("0" = private; " 1 " = public).

The literature offers conflicting points of views on whether the quality of education is affected by the private or public nature of an institution. Private institutions tend to have a reputation for relaxed academic standards, and prospective employers can be sceptical about the quality of the education received by the graduates of such institutions (Bernasconi, 2003). Others have contended that private institutions are more efficient and flexible than public institutions, and that they provide the type and quality of education that students (and their parents) demand (Lockheed and Jiménez, 1994).

In Spain, private universities tend to be younger and to have a larger academic staff, more library resources and better facilities. They are usually smaller, more specialised and offer fewer degree programmes. In contrast, public universities in Spain are typically crowded and have fewer staff; however, they offer more degrees, and their academic level is reported to be higher (E-campus, 2006).

The control variable in the proposed model was included to account for these differences and their potential impact on the variables associated with education quality.

\section{Methodology}

\subsection{Sample and data collection}

To apply and test the proposed model for assessing the quality of marketing-management education, an empirical study was conducted among academic staffs who conduct courses in marketing-management in Spanish universities. For this purpose, a self-completed 
JEFAS

25,49

12

questionnaire was developed and distributed to a cross section of potential respondents. Because there is no comprehensive directory of all university teachers of marketing courses in Spain, a list was created by consulting individual university websites. The final list of potential respondents consisted of individuals who: were designated as teachers of marketing-management courses at their universities and could be contacted by either e-mail or postal mail.

We use the e-mail to present the research and the survey. But, the survey was sent by postal mail in an envelope with the address and postal stamp to facilitate the return of the survey. It is convenient to point out that our survey did not use the online format because a pretesting showed that the survey was perceived too long and very complex for the use of Likert scales.

The questionnaire was sent to the entire target population. To maintain the anonymity of the respondents, they were asked to only respond to their membership in a public or private university. Although ideal would have been to have identified the response rate by university, it was not possible. Thus, we finally settled on the number of professors who responded to the survey, allowing us to maximise the size of the sample and thus use multivariate analysis.

The returned questionnaires were divided into quartiles according to the date on which they were received (with the first quartile containing the earliest returns and the fourth quartile containing the latest returns). Those in the first and fourth quartiles were compared by $t$-tests, indicating that there were no significant statistical differences on average scores for most measures.

The overall response rate from the complete list of potential respondents was 14 per cent (with data from five respondents being discarded because of missing and invalid data). The final sample included 124 teachers in public institutions (70.45 per cent of the sample) and 52 teachers in private institutions (29.55 per cent of the sample). There were 136 male respondents (77.27 per cent) and 40 female respondents (22.73 per cent). Also, respondents were asked to indicate training received outside their home country (none $=40.34$ per cent; some courses $=23.86$ per cent; bachelor's degree $=6.82$ per cent; master's degree $=18.18$ per cent; doctorate $=10.80$ per cent). In relation to their years of experience, the following distribution was obtained: $1-4$ years $=23.9$ per cent; $5-10$ years $=35.2$ per cent; +10 years $=$ 40.9 per cent. By category or academic rank, the following distribution was found: other (lecturer, etc.) $=8.87$ per cent; associate professor $=39.52$ per cent; professor $=30.65$ per cent; full Professor $=20.97$ per cent.

\subsection{Measures}

4.2.1 Resources for teaching. The variable "resources for teaching" was evaluated in terms of eight items:

(1) government funding for higher education;

(2) support for faculty salaries;

(3) support for administrative salaries;

(4) student library resources;

(5) faculty library resources;

(6) technical resources;

(7) political support; and

(8) private funding for higher education. 
The responses were recorded on a scale from 1 to 5 ( $1=$ none; $5=$ extensive). Cronbach's alpha for this variable was 0.8214 , indicating an acceptable degree of reliability for this scale. Factorial analysis grouped all items into one factor (eigenvalue $=2.93474$ ).

4.2.2 Management style. The variable "management style" was assessed by four items derived from Cameron and Quinn (1999). The responses were recorded on a scale from 1 to 5 ( $1=$ strongly disagree; $5=$ strongly agree). The chi-square for this variable was $17.0226(p<$ 0.0007) and Kendall's W measure was 0.263. These results indicate a low (although significant) level of agreement among the respondents' ratings.

The variable management style was recoded as two subsidiary variables:

(1) non-participatory management style (characterised by rules and procedures and by distinguished staff members exercising the most influence); and

(2) participatory management style (characterised by a collegiate and egalitarian management style, regardless of rank).

4.2.3 Teaching methods. The variable "teaching methods" was assessed by seven items derived from Roach et al. (1993) and Clow and Wachter (1996). The responses were recorded on a scale from 1 to 5 ( $1=$ none; $5=$ extensive). The chi-square value for this variable was $345.0293(p<0.0000)$ and Kendall's W measure was 0.3993. These results indicate a low (although significant) level of agreement among the respondents' ratings.

The variable teaching methods was recoded as two subsidiary variables:

(1) structured teaching methods (characterised by class lectures, structured presentations, conferences); and

(2) non-structured teaching methods (characterised by case studies, role-playing, business games and internships).

4.2.4 Evaluation of faculty performance. The variable "evaluation of faculty performance" was assessed by six items derived from Braun and Merrien (1999) and Burton (1983). The responses were recorded on a scale from 1 to $5(1=$ none; $5=$ extensive). The chi-square value for this variable was $70.8143(p<0.0000)$ and Kendall's W measure was 0.3628 . These results indicate low (although significant) level of agreement among respondents' ratings.

The variable evaluation of faculty performance was recoded as two subsidiary variables:

(1) government-imposed criteria (characterised by assessment of faculty performance on the basis of seniority and civil service criteria); and

(2) external stakeholder criteria (characterised by assessment of student surveys, academic and scientific publishing and consultancies, etc.).

4.2.5 Teacher qualification. The variable "teacher qualification" was assessed by three items: teacher's experience, academic level and international experience. Responses with regard to teaching experience were recorded on a scale from 1 to $3(1=1-4$ years; $2=5-10$ years; and $3=$ more than 10 years). Responses with regard to academic level were based on the respondent's highest degree: $(1=$ bachelor's degree; $2=$ master's degree; and $3=$ doctorate). To assess international experience, respondents were asked to indicate whether they received training outside their home country $(1=$ none or some courses; $2=$ bachelor's degree or master's degree; $3=$ doctorate). The chi-square value for this variable was 73.2947, and Kendall's W measure was $0.3290(p<0.0000)$. These results indicate that there was significant agreement among the respondents' ratings. Factorial analysis grouped all items onto one factor (eigenvalue $=1.77515$ ). 
JEFAS

25,49

14

4.2.6 Learning outcomes. The dependent variable of LOMME was evaluated by six items. Respondents were asked whether the educational outcomes of their course:

(1) are adapted to business needs;

(2) are instrumental in solving the country's needs;

(3) develop students' problem-solving skills;

(4) develop student teamwork;

(5) develop innovative solutions; and

(6) provide students with leadership skills.

The responses were recorded on a scale from 1 to $5(1=$ strongly disagree; $5=$ strongly agree).

Cronbach's alpha for this variable was 0.8584 , indicating a high degree of reliability of this scale. Factorial analysis grouped all items onto one factor (eigenvalue $=3.55246$ ).

4.2.7 Competitive outcomes. The second dependent variable, COMME, was evaluated by four items:

(1) reputation and positioning with regard to students;

(2) reputation and positioning with regard to donors;

(3) reputation and positioning with regard to market competitors; and

(4) reputation and positioning with regard to employees.

The responses were recorded on a scale from 1 to $5(1=$ poor positioning; $5=\operatorname{good}$ positioning).

Cronbach's alpha for this variable was 0.8098 , indicating a high degree of reliability of this scale. Factorial analysis grouped all items onto one factor (eigenvalue $=2.58161$ ).

\section{Results}

5.1 Descriptive statistics

Descriptive statistics, including means and standard deviations, of the variables are reported in Table 1.

\begin{tabular}{lcr}
\hline Variables & Mean & SD \\
\hline Resources for teaching & 2.09 & 0.68 \\
Teacher qualification & 1.98 & 0.87 \\
Non-participatory style & 3.09 & 0.69 \\
Participatory style & 2.72 & 1.10 \\
Structured teaching methods & 4.02 & 0.67 \\
Non-structured methods & 2.19 & 0.72 \\
Government criteria & 3.36 & 0.75 \\
External criteria & 2.78 & 0.89 \\
Learning outcomes & 3.30 & 0.88 \\
Competitive outcomes & 3.29 & 0.79
\end{tabular}

Table 1.

Note: $n=176$

of variables

Source: Own elaboration 


\subsection{Data analysis}

Three procedures were used in data analysis:

(1) correlation matrix;

(2) multivariate analysis of variance (MANOVA); and

(3) two-stage least squares regression analysis.

MANOVA was chosen (rather than structural equation modelling) because it is a suitable technique for testing theory in the early stages of development, when research questions are more concerned with the existence of relationship than with their strength (Pedhauzer and Schmelkin, 1991). If the results are significant, it is appropriate to conduct individual multiple regression analyses for each dependent variable (which was done in this study).

The results of the correlation matrices between the independent variables and the dependent variables are shown in Table 2 (learning outcomes) and Table 3 (competitive outcomes). These findings suggested partial acceptance of the hypotheses.

A MANOVA test was used to assess the overall effects of the independent variables on the dependent variables (learning outcomes and competitive outcomes). The multivariate $F$ value was significant (Wilks' lambda: $0.28 ; p=0.000$ ), which showed that the dependent variables were related to variations in the independent variables.

\subsection{Testing of hypotheses}

The third data-analysis procedure used a two-stage least squares regression analysis (with an SPSS statistical package) to assess the effect of each of the model variables on the two dependent variables (LOMME and COMME).

5.3.1 Hypothesised relationships with learning outcomes. Table 4 shows the results of the regression analysis with LOMME as the dependent variable. The results indicate that some of the hypothesised relationships of the model were statistically significant (at $p<0.01$ ). The independent variables explained about 33 per cent of the variation in the LOMME.

Table 4 also shows the results of testing $H 1 a$, which proposed that a higher level of resource availability is associated with a higher level of learning outcomes. The positive relationship between resources and learning outcomes was confirmed when the control variable (type of university) was included (Model 2). This shows that the hypothesised relationship is conditioned by the type of institution (public or private).

The results also confirm the positive relationship between a participatory management style and the level of LOMME, as proposed by H2.1a. (In contrast, the exploratory results shown in Table 3 suggest that a non-participatory management style did not have a positive relationship with the learning outcomes of an educational institution.) When the control variable (type of university) was added (Model 2), the positive relationship was enhanced, suggesting that the influence of the management style on learning outcomes is affected by the different work environments of public and private universities. These results might be due to the fact that private universities often have more freedom in decision-making than public universities, where the work environment is more likely to be conditioned by bureaucratic rules and controls.

H3 proposed that teaching methods influenced LOMME. The results in Table 3 confirm $H 3.1 a$, which proposed that non-structured teaching methods improve educational outcomes. Although this was a strong and significant relationship, it was also sensitive to differences in the methods used in public and private universities.

H4 proposed that methods used in evaluating faculty performance were related to LOMME. Table 4 shows that the use of external stakeholder criteria (student surveys, 
JEFAS

25,49

16

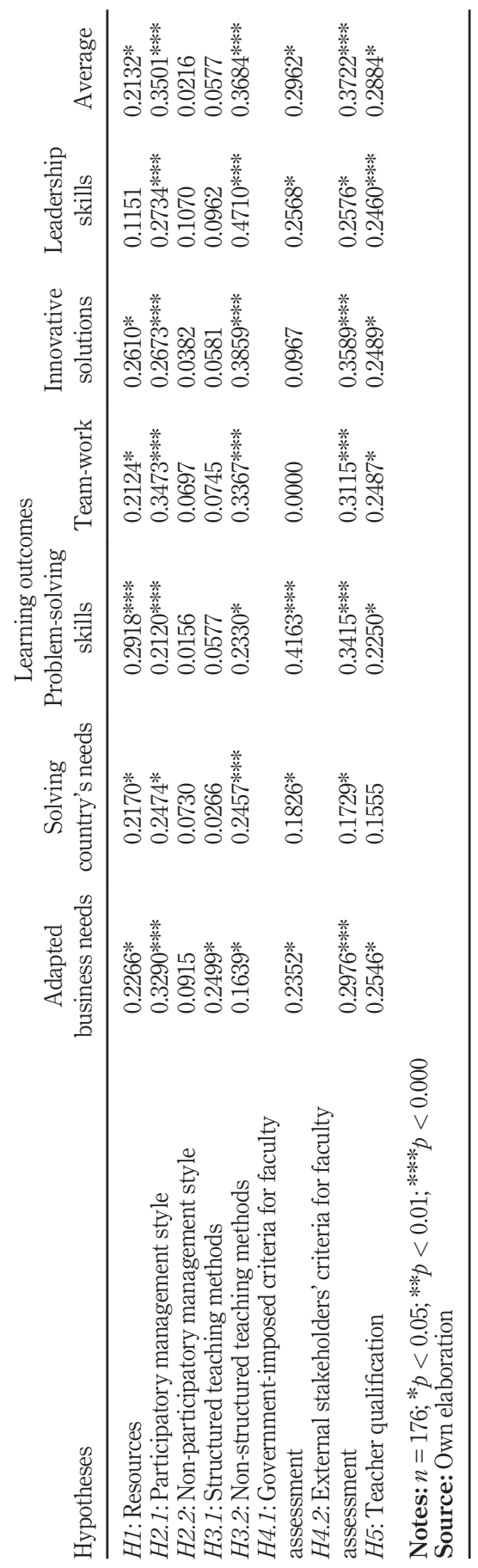

Table 2.

Correlation matrix of learning outcomes and model variables

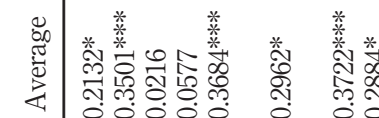

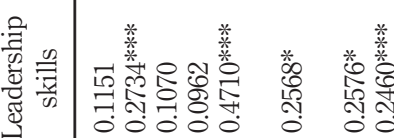

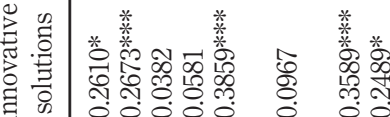

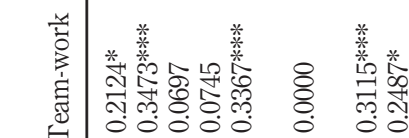

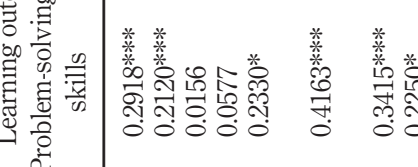

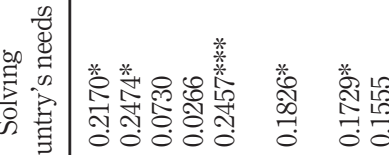

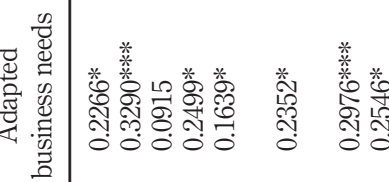




\begin{tabular}{|c|c|c|c|c|c|c|}
\hline Hypotheses & Students & $\begin{array}{l}\text { Competitive } \\
\text { Donors, market }\end{array}$ & $\begin{array}{l}\text { e outcomes } \\
\text { Competitors }\end{array}$ & Employees & Average & $\begin{array}{r}\text { education } \\
\text { eduatiom }\end{array}$ \\
\hline H1: Resources & $0.2026^{*}$ & 0.1424 & $0.1805^{*}$ & $0.2391^{* *}$ & $0.2509 *$ & \\
\hline H2.1: Participatory management style & $0.1901^{*}$ & 0.1109 & 0.0619 & $0.3786 * *$ & $0.2939 * *$ & \\
\hline H2.2: Non-participatory management style & 0.0096 & 0.0251 & 0.0538 & $0.3769 * *$ & $0.2656^{*}$ & \\
\hline H3.1: Structured teaching methods & 0.0795 & 0.0971 & $0.1543^{*}$ & $0.1556 *$ & 0.1365 & \\
\hline $\begin{array}{l}\text { H3.2: Non-structured teaching methods } \\
\text { H4.1: Government-imposed criteria for }\end{array}$ & $0.1725^{*}$ & 0.0647 & 0.0490 & $0.1596^{*}$ & $0.1431^{*}$ & 17 \\
\hline faculty evaluation & 0.0930 & $0.2241 * *$ & $0.2396^{* *}$ & $0.1538^{*}$ & $0.1611^{*}$ & \\
\hline $\begin{array}{l}\text { H4.2: External stakeholder's criteria for } \\
\text { faculty evaluation }\end{array}$ & 0.2867 *** & $0.2699 * *$ & 0.1202 & $0.1906^{*}$ & $0.2860 * *$ & $\begin{array}{r}\text { Table } 3 . \\
\text { Correlation matrix of }\end{array}$ \\
\hline H5: Teacher qualification & $0.2324^{* *}$ & $0.1748^{*}$ & $0.2153^{* *}$ & 0.0682 & $0.1521^{*}$ & \\
\hline \multicolumn{6}{|c|}{$\begin{array}{l}\text { Notes: } n=176 ; * p<0.05 ; * * p<0.01 ; * * * p<0.000 \\
\text { Source: Own elaboration }\end{array}$} & $\begin{array}{r}\text { outcomes and model } \\
\text { variables }\end{array}$ \\
\hline
\end{tabular}

\begin{tabular}{lcc}
\hline Variables & Model 1 & Model 2 \\
\hline H1a: Resource availability & $1.452^{+}$ & $2.519^{*}$ \\
H2.1a: Participatory management style & $2.771^{*}$ & $3.370^{* *}$ \\
H3.1a: Non-structured teaching methods & $3.210^{* *}$ & $3.746^{* *}$ \\
H4.2a: External stakeholder criteria for faculty evaluation & $1.893^{+}$ & $2.764^{* *}$ \\
H5a: Teacher qualification & $2.915^{*}$ & $1.336^{+}$ \\
Summary statistics & & \\
Multiple $R$ & & 0.59774 \\
$R^{2}$ & 0.55470 & 0.35729 \\
Adjusted $R^{2}$ & 0.30769 & 0.32693 \\
$\triangle R^{2}$ & 0.27781 & 0.04912 \\
$F$-statistic & & 11.76676 \\
$p$ & 10.29636 & 0.0000
\end{tabular}

Notes: $n=176 ;{ }^{+} p<0.10 ;{ }^{*} p<0.05 ; * * p<0.01 ; * * * p<0.000$

Source: Own elaboration

Table 4.

Two-stage least squares regression analysis with LOMME as dependent variable

academic and scientific publishing, consultancies) in evaluating faculty had a positive relationship with learning outcomes, as proposed by $H 4.2 a$. However, the influence of these criteria on learning outcomes was appreciable only when the control variable (type of university) was incorporated (Model 2). The explanation for this finding could be that private institutions are more likely to base their evaluation on external (or market) criteria, whereas public universities are more likely to use government-imposed evaluation criteria (seniority and civil service criteria).

$H 5 a$, which proposed a positive relationship between teacher qualification and the learning outcomes, was partially confirmed. This relationship was previously shown to exist in Spain in a qualitative exploratory study by Cambra and Cambra (2003); however, the relationship in the present study was weaker - because the control variable (type of university) was included in this study. It would thus seem that the positive relationship is conditioned by the fact that Spanish universities differ in terms of faculty-accreditation criteria. In Spain, only public universities control teaching accreditation; however, there have recently been demands for similar regulation in the private sector. 
JEFAS

25,49

18

In summary, the results show that higher levels of educational capabilities (inputbased, managerial, organisational and technical organisational) have a positive relationship with learning outcomes in marketing-management education in Spanish universities.

5.3.2 Hypothesised relationships with competitive outcomes. Table 5 shows the results of the regression analysis with COMME as the dependent variable. The results show that several hypothesised relationships in the model were statistically significant (at $p<0.01$ ). The independent variables explained approximately 42 per cent of the variation in the COMME.

$H 1 b$, which proposed that a positive relationship exists between availability of resources and the level of COMME, was confirmed. The relationship was enhanced with the inclusion of the control variable (type of university) (Model 2).

The findings also confirm $H 2.1 b$, which proposed that a positive relationship exists between a participatory management style and competitive outcomes. The results also support $H 3.1 b$, which proposed a positive relationship between non-structured teaching methods and COMME; this relationship was also enhanced when the control variable (type of university) was included (Model 2).

The results also show that the use of external stakeholder criteria in evaluating faculty performance (student surveys, academic and scientific publishing criteria, consultancies) had a positive relationship with COMME, as proposed by $H 4.2 b$; indeed, the use of external stakeholder criteria in the evaluation of faculty performance was the most influential independent variable with regard to COMME.

$H 5 b$, which proposed a positive relationship between teacher qualification and COMME, was not confirmed. The initial weak relationship (Model 1) was eliminated when the control variable (type of university) was included.

In summary, the results provide general support for the proposed model, thus substantiating the contention that the suggested variables are reliable in predicting the levels of educational quality (as measured by LOMME and COMME) in marketingmanagement programmes at Spanish universities.

\begin{tabular}{lcc}
\hline Variables & Model 1 & Model 2 \\
\hline$H 1 b:$ Resource availability & $2.016^{*}$ & $2.820^{* *}$ \\
$H 2.1 b:$ Participatory management style & $3.604^{* *}$ & $3.712^{* *}$ \\
H3.1b: Non-structured teaching methods & $2.333^{*}$ & $2.507^{* *}$ \\
H4.1b: Government-imposed criteria for faculty evaluation & $2.398^{*}$ & $2.116^{*}$ \\
H4.2b: External stakeholders' criteria for faculty evaluation & $2.180^{*}$ & $3.944^{* *}$ \\
H5b: Teacher qualification & $1.380^{+}$ & \\
Summary statistics & & \\
Multiple $R$ & 0.5827 & 0.66827 \\
$R^{2}$ & 0.3959 & 0.44659 \\
Adjusted $R^{2}$ & 0.3659 & 0.4196 \\
$\triangle R^{2}$ & 12.64452 & 0.0537 \\
$F$-statistic & 0.0000 & 0.54306 \\
$p$ & & 0.0000 \\
Notes: $n=176 ;{ }^{+} p<0.10 ;{ }^{*} p<0.05 ; * * p<0.01 ; * * * p<0.000$ & & \\
Source: Own elaboration & & \\
\end{tabular}

Table 5.

Two-stage least squares regression analysis with COMME as dependent variable

Source: Own elaboration 


\section{Conclusions, implications and limitations}

The purpose of this study was to propose and test a model of variables for assessing the quality of marketing-management education, which was defined in terms of students' learning outcomes and the university's competitive positioning. The study also examined how the influence of the proposed variables is moderated by the inclusion of a control variable.

There are some theoretical implications in this research. Our results support that the paradigm of "input-process-outcome" is useful to study the quality of education as a productive system, in which inputs are transferred into outcomes. This paradigm permits empirical testing to support that the resources and capabilities used by the institutions in our study affect the quality of their outcomes.

Likewise, this paradigm allows us to integrate the theory of resource dependence. Although this theory was developed to study company performance, the present study confirms that the resource-dependence theory can also be used to explain university competitiveness. Thus, our findings contributed and advanced the existing literature on higher education quality.

These results have important implications for organisational theory, as they suggest that fostering organisational performance is a multicapabilities' endeavour, including organisational capabilities, input-based capabilities, managerial capabilities and technical organisational capabilities, which are essential and interdependent, from the perspective of competitive advantage, these results can support the resource-based perspective that sustainable competitive advantage is the outcome of rational managerial choices regarding the disposition of resources. As a consequence, the study suggests that the implementation of an educational strategy is likely to be most successful when these various teachers and organisational variables are addressed simultaneously.

In term of managerial implication, our research provides some insights and feedback for the administrators of higher education institutions. Our results provide them with the use of managerial strategies for incorporating the resource-capability variables linked to learning outcomes for students and the competitive positioning of universities. Moreover, some scales of this survey (management style, teaching methods, evaluation of faculty performance) are a potential self-diagnostic tool for managers, as they describe the administrative actions that higher education institutions could use to implement competitive strategies for their organisations.

Because marketing-management education influences a firm's competitiveness, practitioners are directly and indirectly affected by the quality of educational outcomes in the country where their firms operate. Therefore, our results are important for a globalised labour market where companies can hire students trained in other European countries. Thus, managers have guidelines to compare the education that candidates have received, according to the resource-capability variables that have been used in their training, which may vary according to the countries where they have been trained.

The study provides guidance to firms that develop training policies for their marketing directors. The results help identify the teaching methods that are the most effective for internal personnel training and indicate the potential skills to be expected of a graduate of a particular university. The learning outcomes included in the study can also assist in setting career-development objectives and the best methods to attain them and provide parameters that managers can use for self-evaluation or employee evaluation.

The findings have several implications for policymakers, especially those responsible for developing policy for Spanish and European education. First, it shows that the respondents believed that several capabilities were at moderate or low levels at their universities. This 
JEFAS

25,49

20

finding is in accordance with the fact that the economic downturn has led many European Union countries to reduce investment in education (Katsarova, 2015).

Secondly, structured teaching methods were found to be common in Spanish universities, and participatory management styles were found to be relatively uncommon in Spanish university marketing departments. These findings are significant for policymakers because it has been claimed that these factors can impede the development of good universities in Spain (Pérez-Díaz, 2006).

The major limitations of this study are common to all research in education. Data were imperfect, and the structures of the educational variables used in the study might well be incomplete (Todd and Wolpin, 2003). Also, the study was limited by the individual and organisational cross-level relationships in the model, as well as the auto-selection bias inherent in the sample. Despite these limitations, the sampling procedure and reliability tests conducted on the variables have ameliorated these difficulties to some extent.

To enhance the validity and generalisation of the research findings, future studies could use more direct objective measures of the theoretical constructs and explore the causal relationships among the variables. In addition, future studies might examine the proposed model with scholars from different countries and from diverse disciplines. Thus, comparative studies might be carried out as a further research.

\section{References}

Adams, D. (1993), "Defining educational quality", Improving Educational Quality Project Publication \#1: Biennial Report, Institute for International Research, Arlington, VA.

Adrian, C. and Palmer, G. (1999), "Toward a model for understanding and improving educational quality in the principles of marketing course", Journal of Marketing Education, Vol. 21 No. 1, pp. 25-33.

Alavi, M., Wheeler, B. and Valacich, J. (1995), "Using IT to reengineer business education: an exploratory investigation of collaborative telelearning", MIS Quarterly, Vol. 19 No. 3, pp. 293-312.

Albers-Miller, N., Straughan, R. and Prenshaw, P. (2001), "Exploring innovative teaching among marketing educators: perceptions of innovative activities and existing reward and support programs", Journal of Marketing Education, Vol. 23 No. 3, pp. 249-259.

Amit, R. and Schoemaker, P. (1993), "Strategic assets and organizational rent", Strategic Management Journal, Vol. 14 No. 1, pp. 33-46.

Athaide, G. (2005), "Design and implementation of an interdisciplinary marketing management course on technology and innovation management", Journal of Marketing Education, Vol. 27 No. 3, pp. 239-249.

Baldwin, T., Bedell, M. and Johnson, J. (1997), "The social fabric of a team-based MBA program: network effects on student satisfaction and performance", Academy of Management Journal, Vol. 40 No. 6, pp. 1369-1397.

Baumgartner, H. and Pieters, R. (2003), "The structural influence of marketing journals: a citation analysis of the discipline and its Sub areas over time", Journal of Marketing, Vol. 67 No. 2, pp. 123-139.

Beeby, C. (1966), The Quality of Education in Developing Countries, Harvard University Press, Cambridge, MA.

Bergadaà, M. (1990), Gestion Et Pédagogie: une Approche Nowvelle Illustrée Par La Methode Des Cas, McGraw Hill, France.

Bernasconi, A. (2003), "Private higher education with an academic focus: Chile's new exceptionalism", International Higher Education, Vol. 32, pp. 18-19. 
Bertolin, J. (2015), "Quality in higher education: from the diversity of conceptions to the relentless conceptual subjectivity”, Creative Education, Vol. 6 No. 22, pp. 2410-2421.

Birnbaum, R. and Deshotels, J. (1999), "Has the academy adopted TQM?", Planning for Higher Education, Vol. 28 No. 1, pp. 29-37.

Bok, D. (1986), Higher Learning, Harvard University Press, Cambridge, MA.

Bok, D. (2003), Universities in the Marketplace: The Commercialization of Higher Education, Princeton University Press, New Jersey.

Boyatzis, R. (1999), "Building on competence: the effective use of managerial talent", in Salaman, G. (Ed.), Human Resource Strategies, Sage Pub, London, pp. 260-272.

Braimoh, D. (2002), "Assuring quality in higher education through research and publishing, spheres of influence: ventures and visions in educational development”, Conference conducted at the meeting of the International Consortium for Educational Development in Higher Education, Western Australia, July.

Braun, D. and Merrien, F.X. (1999), Towards a New Model of Governance for Universities? A Comparative View, Jessica Kingsley, London.

Brewer, D., Gates, S. and Goldman, C. (2002), In Pursuit of Prestige: Strategy and Competition in US higher Education, Transaction, New Brunswick, NJ.

Burton, C. (1983), The Higher Education System: Academic Organization in Cross-National Perspective, University of California Press, Berkeley.

Cambra, J. and Cambra, J. (2003), Aspectos Determinantes De La Calidad De Un Centro Educativo Como Herramienta De Gestión y Diferenciación, II Jornadas Internacionales de Marketing Público y no Lucrativo, Zaragoza.

Cameron, K. and Quinn, R. (1999), Diagnosing and Changing Organisational Culture: based on the Competing Values Framework, Addison-Wesley, Reading, MA.

Campbell, C. and Rozsnyai, C. (2002), "Quality assurance and the development of course programmes", UNESCO, ISBN92-9069-171-3.

Canzer, B. (1997), "Marketing education on the internet: a world wide web based introductory marketing course design for the virtual-U project in distance education at Simon Fraser university", Journal of Marketing Education, Vol. 19 No. 3, pp. 56-65.

Carron, C. and Châu, T. (1996), The Quality of Primary Schools in Different Development Contexts, United Nations Educational, Paris.

Cave, M., Hanney, S., Henkel, M. and Kogan, M. (1997), The Use of Performance Indicators in Higher Education: The Challenge of the Quality Movement, 3rd ed., Jessica Kingsley, London.

Choon Ling, K., Hoi Piew, T. and Chai, L.T. (2010), "The impact of resource input model of education quality on the overall students' perceived service quality”, Canadian Social Science, Vol. 6 No. 2, pp. 125-144.

Clark, K. and Wheelwright, S. (1992), "Competing through development capability in a manufacturingbased organization”, Business Horizons, Vol. 35 No. 4, pp. $29-43$.

Clow, K. and Wachter, M. (1996), "Teaching methodologies used in basic marketing: an empirical investigation”, Journal of Marketing Education, Vol. 18 No. 1, pp. 48-59.

Cooke, P. and Leydesdorff, L. (2006), "Regional development in the knowledge-based economy: the construction of advantage", The Journal of Technology Transfer, Vol. 31 No. 1, pp. 5-15.

Courtney, H., Kirkland, J. and Viguerie, P. (1997), "Strategy under uncertainty", Harvard Business Review, Vol. 75 No. 6, pp. 66-79.

Cova, B., Kassis, J. and Lanoux, V. (1994), "Entre pedagogie nouvelle et pedagogie Serieuse -Les 20 ans d'experience europeenne de l'EAP”, Gérer et comprendre. Juin, pp. 29-42.

Davies, L. and Walker, P. (2014), "Graduates in Italy and Spain have low basic skills, says OECD report”, available at: www.theguardian.com/education/2014/sep/09/italy-spain-graduates-skillsoecd-report-education

Management education 
JEFAS 25,49

22
Diaconescu, M. (2009), "Building a knowledge society in the European union", Buletinul Universităt $i$ i Petrol-Gaze Din Ploieşti, Vol. 61 No. 1, pp. 50-59.

Dill, D. (2003), “Allowing the market to rule: the case of the United States”, Higher Education Quarterly, Vol. 57 No. 2, pp. 136-157.

Dubois, P. (1995), "Propos sur les sciences de gestion en général et sur leur enseignement en particulier", Mélanges En L'honneur D'André, Editions Economica, Paris, 121-133.

E-campus (2006), "Variables de calidad actuals", Portal de Gaceta Universitaria, July, 28, available at: www.tugueb.com/e_campus/2002/06/reportaje/ranking/6.html

El Mundo Digital (2006), "Europa debería invertir el doble en universidad para acercarse a EE.UU. El Mundo Digital”, available at: www.madrimasd.org/informacionIDI/noticias/noticia.asp?id=26167

Eriksson, L. and Hauer, A. (2004), "Mind map marketing: a creative approach in developing marketing skills", Journal of Marketing Education, Vol. 26 No. 2, pp. 174-187.

EUA (2003), "Response to the communication from the commission: the role of the universities in the Europe of knowledge", European University Association, available at: www.eua.be/eua/jsp/en/ upload/Role_Univ_EUA_Response.1065180266813.pdf

European Foundation for Quality Management - EFQM (1995), Self-Assessment. guidelines for Public Sector, Bruselas Education, Belgium.

Fife, J. and Janosik, S. (1999), "Defining and ensuring quality in Virginia higher education", available at: www.via.vt.edu/spring99/highered.html

Fortier, J., Albrecht, B., Grady, S., Burbach, M. and Westrich, A. (1998), "Wisconsin's model academic standards for marketing education", Wisconsin Department of Public Instruction, Bulletin No. 9005, ISBN 1-57337-069-X.

Frackmann, E. (2000), Management and Institutional Autonomy, the Higher Education Management Challenge, Hochschul-Informations-System $\mathrm{GmbH}$, Hannover.

Frost, P. and Fukami, C. (1997), "Teaching effectiveness in the organizational sciences: recognizing and enhancing the scholarship of the teaching", Academy of Management Journal, Vol. 40 No. 6 , pp. 1271-1281.

Glewwe, P. and Jacoby, H. (1994), "Student achievement and schooling choice in low-income countries: evidence from Ghana”, Journal of Human Resources, Vol. 29 No. 3, pp. 843-864.

Grant, R. (1991), "The resource-based theory of competitive advantage: implications for strategy formulation”, California Management Review, Vol. 33 No. 3, pp. 114-135.

Green, P. (1999), Building Robust Competencies, Jossey-Bass, San Francisco.

Greenwald, R., Hedges, L. and Laine, R. (1996), “The effect of school resources on student achievement”, Review of Educational Research, Vol. 66 No. 3, pp. 361-396.

Harvey, L. and Green, D. (1993), "Defining quality", Assessment and Evaluation in Higher Education, Vol. 18 No. 1, pp. 9-34.

Harvey, L. and Knight, P. (1996), Transforming Higher Education, Open University Press, Buckingham.

Henry, S., Kadane, J., Kaufer, J., Laughlin, P., Lindberg, M., Powers, A. and Smith, B. (1997), "Preliminary report of the task force on staff at Carnegie Mellon", available at: www.cmu.edu/ splan/CurrentPlan/StfMar397.html

Heyl, J. and McCarthy, J. (2003), "International education and teacher preparation in the US", Presentation at the national conference Global Challenges and US Higher Education: National Needs and Policy Implications, Duke University, Durham, 24 January.

Holdswoth, D. and Nind, D. (2005), “Choice modelling New Zealand high school seniors' preferences for university education”, Journal of Marketing for Higher Education, Vol. 15 No. 2, pp. 81-104.

Imbs, P. (1995), “Les modes managériales mises en échec?”, Gestion, Vol. 2000 No. 3, pp. 89-104. 
Kaiser, F. and Yonezawa, A. (2003), "System-level and strategic indicators for monitoring higher education in the twenty-first century", Studies on Higher Education, UNESCO, London.

Kaplan, M.D., Piskin, B. and Bol, B. (2010), "Educational blogging: integrating technology into marketing experience", Journal of Marketing Education, Vol. 32 No. 1, pp. 50-63.

Katsarova, I. (2015), "Higher education in the EU: approaches, issues and trends", European Union, available: www.europarl.europa.eu/EPRS/EPRS-IDA-554169-Higher-education-in-the-EU-FINAL.pdf

Kogut, B. and Zander, U. (1996), "What firms do? Coordination, identity, and learning”, Organization Science, Vol. 7 No. 5, pp. 502-518.

Lado, A. and Wilson, M. (1994), "Human resource systems and sustained competitive advantage: a competency based perspective", Academy of Management Review, Vol. 119 No. 4, pp. 699-727.

Lado, A., Boyd, N. and Wright, P. (1992), "A competency based model of sustainable competitive advantage: toward a conceptual integration”, Journal of Management, Vol. 18 No. 1, pp. 77-91.

Leidner, D. and Jarvenpaá, S. (1995), "The use of information technology to enhance management school education: a theoretical view”, MIS Quarterly, Vol. 19 No. 3, pp. 265-291.

Leithwood, K. and Menzies, T. (1998), "A review of research concerning the implementation of sitebased management”, School Effectiveness and School Improvement, Vol. 9 No. 3, pp. 233-285.

Lengnick-Hall, C. (1996), "Customer contributions to quality: a different view of the customer-oriented firm", Academy of Management Review, Vol. 21 No. 3, pp. 791-824.

Lengnick-Hall, C. and Sanders, M. (1997), "Designing effective learning systems for management education: student roles, requisite variety, and practicing what we teach", Academy of Management Journal, Vol. 40 No. 6, pp. 1334-1368.

Lerner, L. (1995), "Making student groups work”, Journal of Management Education, Vol. 19, pp. 123-125.

Lockheed, M. and Jiménez, E. (1994), "Public and private secondary schools in developing countries: what are the differences and why do they persist?", The World Bank. Education and Social Policy Department, ESP Discussion Paper Series, No. 33.

Lombardi, J., Craig, D., Capaldi, E., Gater, D. and Mendonça, S. (2001), Quality Engines: The Competitive Context for Research, the Top American Research Universities, The Center Gainesville, Florida.

McMullen, C. (1998), "Promoting generic skills in marketing education", Paper presented at the ANZMZC Conference, University of Otago, Dunedin.

Martínez, A. (2005), "Los retos de la universidad del siglo XXI”, Expansión, Vol. 5 No. 14, p. 27.

Matsuura, K. (2003), "Round table of ministers of education on quality education for all", Director-General of the United Nations Educational, Scientific and Cultural Organization (UNESCO)- DG/2003/134.

Neave, G. (1998), "The evaluative state reconsidered", European Journal of Education, Vol. 33 No. 3, pp. 265-284.

Pascarella, E. and Terenzini, P. (1991), How College Affects Students: findings and Insights from Twenty Years of Research, Jossey-Bass, San Francisco.

Pawlowski, K. (2004), "Rediscovering higher education in Europe", Studies on Higher Education. UNESCO-CEPES Publications, ISBN 92-9069-180-X.

Pedhauzer, E. and Schmelkin, L. (1991), Measurement, Design and Analysis, Lawrence Erlbaum Associates, Hillsdale, NJ.

Pérez-Díaz, V. (2006), "Dos claves de la discusión sobre la mejora de la universidad: el marco institucional y la cultura", Madrid Análisis, available at: www.madrimasd.org/informacionidi/ analisis/analisis/analisis.asp?id=26456

PHARE (1998), "Quality assurance in higher education: final report and project recommendations", Multicountry Handbook, EU-Phare project. 
JEFAS 25,49
Pickernell, D., Packham, G. and Brooksbank, D. (2010), “A recipe for what? UK universities, enterprise and knowledge transfer: evidence from the federation of small businesses 2008 survey", International Journal of Entrepreneurship and Innovation, Vol. 11 No. 4, pp. 265-272.

Pride, W. and Ferrell, O. (2000), Marketing: Concepts and Strategies, Houghton Mifflin, Boston.

Radford, J., Raaheim, K., de Vries, P. and Williams, R. (1997), "Quantity and quality in higher education”, Resources in Education (RIE), Higher Education Policy, ED415737, Series 40.

Ramina, B. (2003), Impacts to and Measurement of Higher Education Quality, Report prepared within EU 5th Framework program project, Higher Education Reform Network.

REIP (2002), Regional Education Indicators Project, Educational Panorama of the Americas, UNESCO's Regional Office for Education in Latin America and the Caribbean, London.

Roach, S., Johnston, M. and Hair, J. (1993), “An exploratory examination of teaching styles currently employed in marketing education: developing a typology and its implications for marketing students", Journal of Marketing Education, Vol. 15 No. 3, pp. 32-38.

Rowley, D. and Rowley, B. (2000), "Information age challenges to management education and administration in the new millennium”, International Journal of Management, Vol. 17 No. 1, pp. 45-52.

Rowley, D., Lujan, H. and Dolence, M. (1998), Strategic Choices for the Academy: how Demand for Lifelong Learning Will Re-Create Higher Education, Jossey-Bass, San Francisco.

Royo, S. (2010), "Portugal and Spain in the EU: paths of economic divergence (2000-2007)", Análise Social, Vol. 45 No. 195, pp. 209-254.

Salam, A. (2015), "Input, process and output: system approach in education to assure the quality and excellence in performance”, Bangladesh Journal of Medical Science, Vol. 14 No. 1, pp. 1-2.

Salter, B. and Tapper, T. (2000), "The politics of governance in higher education: the case of quality assurance”, Political Studies, Vol. 48 No. 1, pp. 66-87.

Scheerens, J., Luyten, H. and van Ravens, J. (2011), "Perspectives on educational quality", in Scheerens, J., Luyten, H. and van Ravens, J. (Eds), Perspectives on Educational Quality, Springer Briefs in Education, Springer, Dordrecht, Vol. 1.

Scott, G. (2003), "Effective change management in higher education", EDUCAUSE Review, Vol. 38 No. 6, pp. 64-80.

Sinkovics, R. and Schlegelmilch, B. (2000), "Marketing academics in Austria, Germany and Switzerland: Humboldt's ideals give way to performance pressure”, Journal of Marketing Management, Vol. 16 No. 7, pp. 745-759.

Srikanthan, G. and Dalrymple, J. (2003), "Developing alternative perspectives for quality in higher education”, International Journal of Educational Management, Vol. 17 No. 3, pp. 126-136.

Stern, B. and Tseng, L. (2002), "Do academics and practitioners agree on what and how to teach the undergraduate marketing research course?", Journal of Marketing Education, Vol. 24 No. 3, pp. 225-232.

Straughan, R. and Albers-Miller, N. (2000), "Marketing education research: credit for the advancement of our own profession?”, Journal of Marketing Management, Vol. 16 No. 7, pp. 793-813.

Strauss, R. and Vogt, W. (2001), "It's what you know, not how you learned to teach it: evidence from a study of the effects of knowledge and pedagogy on student achievement", Paper presented at the annual meeting of American Educational Finance Association, Cincinnati, $\mathrm{OH}$.

Tapp, A. (2004), "The changing face of marketing academia: what can we learn from commercial market research and practitioners?”, European Journal of Marketing, Vol. 38 Nos 5/6, pp. 492-499.

Todd, P. and Wolpin, K. (2003), "On the specification and estimation of the production function for cognitive achievement”, The Economic Joumal, Vol. 113 No. 485, pp. 3-33.

Tumer, D. and Crawford, M. (1994), "Managing current and future competitive performance: the role of competences", in Hamel, G. and Heene, A. (Eds), Competence Based Competition, Wiley and Sons, New York, NY, pp. 241-264. 
UNESCO (1998), "Higher education in the twenty-first century vision and action", World Conference on Higher Education, Paris, October.

UNESCO (2002), "Redefining quality education”, Chapter Two, Second International Forum on Quality Improvement in Education: Policy, Research and Innovative Practices in Improving Quality of Education, UNESCO, Beijing.

UNICEF (2000), "Defining quality in education", UNICEF Programme Division, Education, Document No. UNICEF/PD/ED/00/02.

Vanguardia Digital (2006), "Universidad y future: la vanguardia digital”, available at: http://selene.uab. es/ce-documentacio-europea/CDE \%20Informacions/Annexes \%200602/0602061.htm

Vazzana, G., Elfrink, J. and Bachmann, D. (2000), “A longitudinal study of total quality management processes in business colleges", Journal of Education for Business, Vol. 76 No. 2, pp. 69-74.

Verdin, P. and Williamson, P. (1994), "Core competences, competitive advantage and market analysis: forging the links", in Hamel, G. and Heene, A. (Eds), Competence Based Competition, Wiley and Sons, New York, NY, pp. 77-110.

Walker, R., Hanson, D., Nelson, L. and Fisher, C. (1998), "A case for more integrative multi-disciplinary marketing education”, European Journal of Marketing, Vol. 32 Nos 9/10, pp. 803-812.

Walvoord, B., Carey, A., Smith, H., Soled, S., Way, P. and Zorn, D. (2000), “Academic departments: how they work, how they change", ERIC Clearinghouse on Higher Education, Washington DC -ED446725, George Washington University, Washington, DC.

Watty, K. (2003), "When will academics learn about quality?”, Quality in Higher Education, Vol. 9 No. 3 , pp. 213-221.

Woodhouse, D. (1996), "Quality assurance: international trends, preoccupations and features", Assessment and Evaluation in Higher Education, Vol. 21 No. 4, pp. 347-356.

Wyman, W. (2001), "The progress of education reform: teaching quality", Education Commission of the States, Vol. 2 No. 4.

Zhou, N. (2000), "Promoting quality education in the New Century: new contexts, visions, approaches and UNESCO strategies", Second International Forum on Quality Improvement in Education, UNESCO, Paris.

\section{Further reading}

Klein, K., Dansereau, F. and Hall, R. (1994), "Levels issues in theory development, data collection, and analysis", Academy of Management Review, Vol. 19 No. 2, pp. 195-229.

Morse, J. and Santiago, G. (2000), "Accreditation and faculty: working together", Academe, Vol. 86 No. 1, pp. 30-34.

\section{Corresponding author}

Jaime Rivera can be contacted at: rjaime@pucp.pe

For instructions on how to order reprints of this article, please visit our website:

www.emeraldgrouppublishing.com/licensing/reprints.htm

Or contact us for further details: permissions@emeraldinsight.com 